\title{
PENGARUH PENGGUNAAN MEDIA VIDEO TERHADAP HASIL BELAJAR SISWA PELAJARAN PEKERJAAN DASAR ELEKTROMEKANIK KELAS X TITL DI SMK NEGERI 3 SINGARAJA
}

\author{
I M. Ambara ${ }^{1}$, A. Adiarta ${ }^{2}$, G. Indrawan ${ }^{3}$ \\ ${ }^{1,2}$ Prodi Pendidikan Teknik Elektro, Universitas Pendidikan Ganesha, Singaraja \\ ${ }^{3}$ Prodi Teknik Elektronika, Universitas Pendidikan Ganesha, Singaraja \\ e-mail: imade.ambara@yahoo.com, agus.adiarta@undiksha.ac.id, gindrawan@undiksha.ac.id
}

\begin{abstract}
Abstrak
Penelitian ini bertujuan untuk mengetahui pengaruh penggunaan media video terhadap hasil belajar siswa kelas X Teknik Instalasi Tenaga Listrik di SMK Negeri 3 Singaraja Tahun Ajaran 2017/2018.Penelitian ini menggunakan metode Quasi Experimental Design dengan desain penelitian Posttest-Only Control Design. Populasi penelitian ini adalah seluruh kelas X Teknik Instalasi Tenaga Listrik SMK Negeri 3 Singaraja, dengan sampel kelas X Teknik Instalasi Tenaga Listrik 3 sebagai kelas eksperimen dan X Teknik Instalasi Tenaga Listrik 2 sebagai kelas kontrol. Teknik pengambilan data sampel dilakukan secara random sampling. Teknik pengumpulan data menggunakan metode tes. Teknik analisis data yang digunakan adalah uji-t.Hasil penelitian menunjukan bahwa rata-rata hasil posttest hasil belajar Pekerjaan Dasar Elektromekanik kelas eksperimen yaitu 72,60 , kelas kontrol yaitu 62,93 dan nilai $t_{\text {hitung }} 5,210>t_{\text {tabel }} 1.998$. Artinya ada perbedaan yang signifikan antara hasil post-test kelas eksperimen yang menggunakan media video pembelajaran dengan kelas kontrol yang tidak menggunakan media video, sehingga terdapat pengaruh positif penggunaan media video terhadap hasil belajar siswa kelas X TITL di SMK Negeri 3 Singaraja Tahun Ajaran 2017/2018.
\end{abstract}

Kata kunci: media video, hasil belajar, pekerjaan dasar elektromekanik

\begin{abstract}
This study aimed to determine the effect of the use of video as learning media in classroom as the students learning outcomes especially for the students in the class $X$ of Electrical power installation techniques in SMK N 3 Singaraja on 2017/2018. This study used Quasi Experimental Design method with the research design using Posttest-Only Control Design. The populations of this study came from all of the students in the class $X$ of Electrical power installation techniques in SMK N 3 Singaraja, which used students in the class $X$ of Electrical power installation techniques 3 in SMK N 3 Singaraja as experimental class, and used students in the first grade of Electrical power installation techniques 2 in SMK N 3 Singaraja as control class. The sampling technique of sample data is done by random sampling. The data collecting technique in this study used test method. T-test was used us the data analysis technique. The result of this study showed that the average of the result of the post-test are 72,60 for experiment class, 62,93 for the control class, and the result of $t_{\text {hitung }} 5,210>t_{\text {tabel }} 1.998$. It means that there issignificant difference between post test in experiment class that use video as learning media with the control class which is not use the video as learning media, so there is positive impact of the use of video as learning media for the student in the class X of TITL in SMK N 3 Singaraja on 2017/2018.
\end{abstract}

Keywords: video as the media, result of the study, basic electromechanical work

\section{Pendahuluan}

Pendidikan merupakan hal yang terpenting dalam kehidupan manusia, hal ini berarti manusia berhak mendapat dan berharap selalu berkembang dalam pendidikan. Untuk mewujudkan hal itu, upaya yang dilakukan pemerintah dalam meningkatkan mutu pendidikan bagi Bangsa Indonesia adalah diterbitkannya Undang-Undang Nomor 20 Tahun 2003 tentang sistem pendidikan nasional. Dalam pasal 3 dijelaskan bahwa pendidikan nasional berfungsi untuk (1) meningkatkan kemampuan dan membentuk watak serta peradaban bangsa yang 
bermatabat dalam rangka mencerdaskan kehidupan bangsa, (2) menjadikan manusia beriman dan bertaqwa kepada Tuhan Yang Maha Esa, (3) menumbuhkan ahlak mulia yang berilmu, cakap, kreatif, dan mandiri, serta (4) menjadikan warga Negara yang demokratis dan bertanggung jawab. Berdasarkan uraian tersebut, dapat dikatakan bahwa untuk mencapai tujuan pendidikan maka pendidikan merupakan hal yang wajib dimiliki oleh setiap orang dalam meningkatkan kualitas pendidikan.

Peningkatan kualitas pendidikan, tenaga pendidik (guru) dan peserta didik (siswa) memiliki peran penting dalam proses pembelajaran untuk pencapaian tujuan pendidikan, khususnya dalam menerima materi pelajaran. Keberhasilan dan kualitas pendidikan di sekolah ditunjukkan dari prestasi belajar siswa yang tidak dapat dipisahkan dari proses belajar.

Proses belajar adalah unsur yang paling penting dalam pendidikan. Pelaksanaan proses belajar mengajar yang baik menunjukkan tercapainya tujuan pendidikan. Pencapaian tujuan pada proses pembelajaran didukung oleh peran guru yang mempunyai kompetensi dan kinerja yang baik. Guru yang mempunyai kinerja yang baik akan mampu menumbuhkan semangat dan motivasi belajar siswa yang lebih baik sehingga terjadi peningkatan hasil belajar siswa. Salah satu usaha untuk meningkatkan lulusan yang berkualitas yaitu dengan menyempurnakan proses belajar mengajar. Peranan proses belajar mengajar di sekolah sangat penting karena disinilah semua ilmu akan diajarkan ke pada peserta didik, untuk itu proses pembelajaran harus dilaksanakan dengan sebaik-baiknya, baik dari perencanaan, pelaksanaan ataupun evaluasi agar tujuan pembelajaran dapat dicapai sesuai dengan yang diharapkan.

Proses pembelajaran pada umumnya menuntut setiap guru untuk bisa membuat suasana kelas yang kondusif dan menyenangkan, sehingga dapat membantu siswa dalam mencapai tujuan yang telah ditetapkan. Salah satu cara yang dapat digunakan guru adalah dengan menggunakan media pembelajaran yang menarik dan efektif. Dari pengertian pendidikan jelas bahwa pelaksanaan pendidikan itu pada umumnya adalah mengembangkan mutu dan potensi sumber daya manusia untuk membangun bangsa yang lebih maju. Adanya perkembangan ilmu pengetahuan dan teknologi juga akan berpengaruh terhadap kualitas sistem pembelajaran di sekolah. Artinya, dengan kehadiran teknologi yang modern sekolah dituntut untuk lebih kreatif dalam membuat pembelajaran menjadi menarik dan efektif, baik dalam proses pembelajaran maupun media pembelajaran sehingga siswa akan menjadi senang dan tidak bosan selama proses pembelajaran berlangsung dan memperoleh hasil belajar maksimal.

Untuk mencapai tujuan pembelajaran yang optimal sangatlah perlu menggunakan media sebagai alat bantu dalam proses pembelajaran. Penggunaan media video memiliki banyak manfaat yang diberikan yaitu; 1) Sangat membantu guru dalam mencapai efektifitas pembelajaran khususnya pada mata pelajaran yang mayoritas praktek; 2) Memaksimalkan pencapaian tujuan pembelajaran dalam waktu yang singkat; 3) Dapat merangsang minat belajar siswa untuk lebih mandiri; 4) siswa dapat berdiskusi atau minta penjelasan kepada teman sekelasnya; 5) siswa dapat belajar untuk lebih berkonsentrasi; 6) Daya nalar siswa lebih terfokus dan lebih kompeten; 7) siswa menjadi aktif dan termotivasi untuk memprakteka latihan-latihan; 8) siswa dapat menayangkannya di rumah karena materi sudah dalam format film atau CD,; 9) Memenuhi tuntutan kemajuan zaman pendidikan, khususnya dalam penggunaan bidang media teknologi; 10) Memberikan daya pemahaman keterampilan yang lebih terstruktural.

Setelah memperhatikan manfaat media pembelajaran dan macam-macam media pembelajaran, maka peneliti akan menggunakan media pembelajaran audio-visual yang berupa video pembelajaran dalam penelitian ini. Media video yang digunakan dalam proses belajar mengajar memiliki banyak manfaat dan keuntungan, diantaranya adalah video merupakan pengganti alam sekitar dan dapat menunjukkan objek yang secara normal tidak dapat dilihat siswa seperti materi proses pencernaan makanan dan pernafasan, video dapat menggambarkan suatu proses secara tepat dan dapat dilihat secara berulang-ulang, video juga mendorong dan meningkatkan motivasi siswa untuk tetap melihatnya. 
Hasil observasi yang telah dilakukan di SMK Negeri 3 Singaraja Jurusan Teknik Instalasi Tenaga Listrik kelas X pada mata pelajaran pekerjaan dasar elektromekanik. Mata pelajaran pekerjaan dasar elektromekanik merupakan pelajaran yang banyak memperkenalkan peralatan tangan, cara penggunaan, fungsi peralatan, dan keselamatan dalam bekerja. Berdasarkan pengamatan pada beberapa siswa terlihat kurang menikmati saat guru memaparkan materi pada proses pembelajaran sehingga mengakibatkan hasil yang didapatkan menjadi kurang baik.

Siswa kelas X Teknik Instalasi Tenaga Listrik di SMK Negeri 3 Singaraja memiliki ketertarikan yang sulit untuk dipenuhi dan materi yang diberikan sulit untuk dipahami oleh siswa. Sulitnya memahami sebuah materi dikarenakan kurangnya ketertarikan siswa dalam mengikuti proses belajar menyebabkan hasil belajar yang didapatkan menjadi kurang maksimal. Bila ketertarikan siswa dapat terpenuhi maka siswa akan lebih mudah untuk memahami materi yang diberikan sehingga diperlukan sebuah ketertarikan dalam proses belajar untuk dapat lebih memahami materi yang diberikan. Perlu sebuah alat bantu agar siswa menjadi lebih tertarik saat guru memaparkan sebuah materi, penggunaan alat bantu seperti video akan membuat siswa menjadi lebih tertarik dalam menyimak materi pembelajaran sehingga hasil belajar setiap siswa menjadi maksimal.

Berdasarkan permasalahan tersebut, maka penulis tertarik untuk melakukan penelitian dengan judul "Pengaruh Penggunaan Media Video Terhadap Hasil Belajar Siswa dalam Mata Pelajaran Pekerjaan Dasar Elektromekanik Kelas X TITL di SMK Negeri 3 Singaraja Tahun Ajaran 2017/2018". Berdasarkan uraian latar belakang yang telah dikemukakan diatas, dapat dirumuskan permasalahan sebagai berikut."Apakah terdapat pengaruh penggunaan media video terhadap hasil belajar siswa kelas X Teknik Instalasi Tenaga Listrik dalam mata pelajaran pekerjaan dasar elektromekanik di SMK Negeri 3 Singaraja?" Sejalan dengan rumusan masalah diatas, tujuan penelitian ini adalah untuk mengetahui apakah terdapat pengaruh penggunaan media video terhadap hasil belajar siswa kelas $X$ Teknik Instalasi Tenaga Listrik dalam mata pelajaran ppekerjaan dasar elektromekanik di SMK Negeri 3 Singaraja.

\section{Metode}

Pada penelitian ini tidak semua variabel dan kondisi eksperimen dapat diatur dan dikontrol secara ketat. Oleh karena itu, penelitian ini dikategorikan penelitian eksperimen semu (quasi eksperiment). Desain eksperimen yang digunakan adalah Posttest-Only Control Disegn yang memiliki ciri dua kelompok yang dipilih secara random. Kelompok yang diberi perlakuan disebut kelompok eksperimen dan kelompok yang tidak diberi perlakuan disebut kelompok kontrol.Desain kelompok eksperimen dan kontrol dapat digambarkan seperti Tabel 1.

Tabel 1. Desain Penelitian

\begin{tabular}{ccc}
\hline Kelompok & Treatment & Post-test \\
\hline Eksperimen & $\mathrm{X}$ & $\mathrm{O}_{2}$ \\
\hline Kontrol & & $\mathrm{O}_{4}$ \\
\hline
\end{tabular}

Prosedur yang dilakukan dalam penelitian ini seperti: 1) menentukan sekolah yang dijadikan lokasi penelitian yaitu SMK Negeri 3 Singaraja; 2) menentukan populasi penelitian yaitu siswa kelas X TITL di SMK Negeri 3 Singaraja; 3) melakukan uji kesetaraan pada kelas-kelas anggota populasi dengan uji ANAVA satu jalur; 4) menentukan sampel penelitian berdasarkan hasil uji kesetaraan; 5) setelah didapatkan dua kelas sebagai sampel, selanjutnya diundi untuk menetukan kelompok eksperimen dan kelompok control; 6) menyusun Rencana Pelaksanaan Pembelajaran (RPP); 7) membuat media pembelajaran yang digunakan dalam proses pembelajaran pada kelompok eksperimen: 8) mengkonsultasikan media video kepada dosen ahli; 9) memberikan materi kepada kelas 
kontrol dengan menerapkan pembelajaran konvensional; 10) memberikan perlakuan kepada kelas eksperimen dengan menggunakan media video; 11) mengkonsultasikan intrumen tes hasil belajar kepada guru bidang studi dan dosen ahli, mangadakan validasi instrument penelitian yaitu soal-soal pekerjaan dasar elektromekanik; 12) memberikan post-test baik pada kelas eksperimen maupun control; 13) menganalisis hasil penelitian untuk menguji hipotesis yang diajukan apakah $\mathrm{HO}$ diterima atau ditolak.

Populasi adalah wilayah generalisasi yang terdiri atas: objek/subyek yang mempunyai kualitas dan karakteristik tertentu yang ditetapkan oleh peneliti untuk dipelajari dan kemudian ditarik kesimpulan (Sugiyono, 2015:117). Populasi dalam penelitian ini adalah seluruh siswa kelas XTITL SMK Negeri 3Singaraja. Banyaknya anggota populasi dalam penelitian ini adalah 106 siswa yang tersebar ke dalam tiga kelas.

Teknik random dengan sistem undian dilakukan karena semua kelas dianggap memiliki kemampuan dan kesempatan yang sama untuk menjadi kelompok eksperimen maupun kelompok kontrol. Cara pengambilan kelas sampel dalam sistem undian tersebut adalah kedua kelas yang muncul dalam undian langsung dijadikan sebagai kelas sampel. Dari kedua kelas tersebut akan diundi kembali untuk menentukan satu kelompok kontrol dan satu kelompok eksperimen. Pada kelompok eksperimen diberikan media video dan pada kelompok kontrol tidak diberikan media video.

Penentuan sampel dalam penelitian ini dilakukan dengan teknik random sampling di mana setiap kelas memiliki kesempatan yang sama untuk dipilih sebagai sampel. Sebelum dilakukan pengambilan sampel secara acak, akan dilakukan uji kesetaraan dengan menggunakan Analisis Varians (ANAVA) satu jalur. Uji kesetaraan ini dilakukan untuk memperlihatkan bahwa kelas-kelas pada populasi yang digunakan setara. Data yang digunakan dalam melakukan uji kesetaraan ini adalah nilai ulangan harianpekerjaan dasar elektromekanik siswa. Hal ini didasari atas pertimbangan bahwa nilai ulangan harian siswa merupakan nilai murni, yang diperoleh melalui tes dan mencerminkan kemampuan yang dimiliki oleh siswa. Kemudian dua kelas dijadikan sebagai sampel yang akan diundi lagi untuk menentukan satu kelas eksperimen dan satu kelas kontrol. Hasilnya adalah terpilihnya kelas eksperimen, yaitu kelas XTITL3 dan kelas kontrol, yaitu kelas XTITL 2.

Desain penelitian yang digunakan adalah posttest-only control group design, di mana kelompok kontrol adalah kelas yang diberikan pembelajaran tidak menggunakan media video, sedangkan kelompok eksperimen adalah kelas yang diberikan pembelajaran menggunakan media video. Data pada penelitian ini adalah hasil belajar siswa. Data kuantitatif yang berupa skor tes hasil belajar, pengumpulan data dilakukan setelah perlakuan. Data setelah perlakuan berupa skor post-test hasil belajar. Metode pengumpulan data yang digunakan dalam penelitian ini adalah dengan metode tes.

Metode tes yang dilakukan adalah post-test (tes akhir), yaitu tes yang dilakukan setelah proses kegiatan belajar mengajar atau setelah menggunakan metode pembelajaran konvesional atau media video. Sesuai dengan tujuannya tes akhir ini digunakan untuk mengukur dan membandingkan peningkatan rata-rata hasil belajar peserta didik pada mata pelajaran pekerjaan dasar elektromekanik. Hasil belajar pekerjaan dasar elektromekanik siswa (post-test) adalah skor yang diperoleh siswa dalam menyelesaikan suatu tes pekerjaan dasar elektromekanik dalam aspek kognitif (pengetahuan) setelah mengikuti proses pembelajaran. Pengukuran hasil belajar pekerjaan dasar elektromekanik siswa diukur dengan tes hasil belajar.

Sebelum soal digunakan untuk mengukur hasil belajar siswa pada kelas sampel, soal tes terlebih dahulu diujicobakan. Selanjutnya hasil uji coba kemudian dianalisis dan siap digunakan untuk mengukur hasil belajar siswa dari kelompok penelitian. Suatu tes dikatakan baik sebagai alat ukur hasil belajar jika memenuhi persyaratan tes, yaitu validitas dan reliabilitas. Sebelum tes tersebut diberikan, haruslah diuji terlebih dahulu validitas dan reliabilitasnya.

Tes hasil belajar dalam mata pelajaran pekerjaan dasar elektromekanik akan menggunakan tes pilihan ganda. Tes yang baik harus memenuhi persyaratan tes yaitu tes 
tersebut valid dan reliabel sehingga sebelum tes tersebut digunakan, haruslah tes tersebut diuji terlebih dahulu validitas dan reliabilitasnya. Uji coba bertujuan untuk mendapatkan gambaran secara empirik apakah instrumen penelitian berupa tes hasil belajar dalam mata pelajaranpekerjaan dasar elektromekanik siswa layak digunakan sebagai instrumen.

Tes hasil belajar dalam mata pelajaran pekerjaan dasar elektromekanik siswa diuji validitas isi melalui uji pakar (uji ahli). Hasil penilaian pakar dianalisis dengan rumus Gregory dan diperoleh validitas isi sebesar 1,00. Kesimpulannya, tingkat validitas isi instrumen adalah sangat tinggi atau layak digunakan. Selanjutnya tes diujicobakan pada siswa Kelas XI TITL 1 dan XITITL3 SMK Negeri3Singaraja. Untuk menguji validitas butir digunakan rumus korelasi biserial. Setelah menguji validitas, dilanjutkan dengan pengujian reliabilitas dengan menggunakan rumus. Berdasarkan hasilperhitungan validitas butir tes diperoleh 34 butir soal valid dari 40 butir soal yangdiujicobakan. Kemudian, dari hasil analisisreliabilitas tes untuk soal yang validdiperoleh bahwa tes tersebut reliabeldengan koefisien reliabilitas 0,71.Berdasarkan kriteria, soal-soal tersebutmemiliki reliabilitas tinggi sehingga soalsoaltersebut layak digunakan dalampenelitian ini. Berdasarkan hasil uji intrumen yang telah dilakukan, didapatkan soal sebanyak 30 yang dapat digunakan untuk mengukur hasil belajar siswa.

Setelah instrumen yang akan digunakan telah selesai diuji maka intrumen tersebut disebar menuju kelas eksperimen dan kontrol untuk mendapatkan hasil belajar siswa setelah diberikan sebuah perlakukan yang berbeda. Setelah mendapat skor, dilanjutkan denganpengujian hipotesis.Sebelum dilaksanakan pengujianhipotesis, data yang diperoleh harusmemenuhi uji asumsi, yaitu: 1) Uji normalitas untuk hasil belajar siswa dalam mata pelajaran pekerjaan dasar elektromekanik denganmenggunakan teknik statistik KolmogrovSmirnov Test dan Shapiro-Wilk Test.Uji normalitas sebaran data dimaksudkan untuk meyakinkan bahwa data yang diperoleh berdistribusi normal, sehingga uji hipotesis dapat dilakukan. Uji normalitas sebaran data menggunakan statistik Kolmogrov-Smirnov Test dan Shapiro-Wilk Test. Data berdistribusi normal apabila angka signifikansi yang dihasilkan lebih besar dari 0,05 . Perhitungan uji normalitas dalam penelitian ini dilakukan dengan bantuan program SPSS 16,0 for windows.2) Uji homogenitas varians untukkeduakelompok denganmenggunakan uji F.Uji homogenitas varians antar kelompok digunakan untuk mengukur apakah sebuah kelompok mempunyai varians yang sama diantara anggota kelompok tersebut. Uji homogenitas juga digunakan untuk menyakinkan bahwa perbedaan yang terjadi pada uji hipotesis benar-benar terjadi antar kelompok. Uji homogenitas varians antar kelompok menggunakan statistik Levene Test. Data memiliki varians yang sama (homogen) apabila angka signifikan yang dihasilkan lebih besar dari 0,05.

Setelah dilakukan perhitungan normalitas dan homogenitas, maka dilakukan analisis data untuk menguji hipotesis yang telah dirumuskan pada kajian pustaka. Uji hipotesis yang digunakan adalah uji hipotesis satu arah dengan taraf signifikan 0,05. Perhitungan uji homogenitas dalam penelitian ini dilakukan dengan bantuan program SPSS 16,0 for windows. Dalam penelitian ini, teknik analisis data dimaksudkan untuk mendeskripsikan hasil belajar siswa sebagai akibat dari perbedaan pembelajaran yang dilakukan antara kelas eksperimen dengan kelas kontrol. Data hasil belajar siswa dianalisis dengan statistik inferensial, yaitu $t$ test.test "t" atau $t$-test adalah salah satu uji statistik parametris yang digunakan untuk menguji hipotesis komparatif dua sampel bila datanya berbentuk interval atau rasio. Perhitungan $t$-test dan semua uji statistik dalam penelitian ini dilakukan dengan bantuan program SPSS 16,0 for windows. Pengujian dilakukan dengan taraf signifikansi $5 \%$.

Uji $t$-test merupakan salah satu statistik parametris, sehingga perlu dilakukan uji asumsi terhadap data hasil belajar siswa. Pengujian asumsi ini meliputi uji normalitas dan uji homogenitas. Uji $t$-test dilakukan untuk menentukan perbedaan yang terjadi pada kelas kontrol dan kelas eksperimen. Semua analisis data ini menggunakan bantuan program SPSS 16.0 for windows pada taraf signifikansi $5 \%$, rumusan hipotesis yang diuji adalah sebagai berikut. Ho: Tidak terdapat pengaruh penggunaan video terhadap hasil belajar siswakelas X TITL dalam mata pelajaran pekerjaan dasar elektromekanik di SMK Negeri 3 Singaraja. Ha: 
Terdapat pengaruh penggunaan video terhadap hasil belajar siswa kelas X TITL dalam mata pelajaran pekerjaan dasar elektromekanik di SMKNegeri 3 Singaraja.

\section{Hasil dan Pembahasan}

Pada bagian ini disajikan hasil penelitian tentang pengaruh penggunaan media video terhadap hasil belajar siswa. Adapun hasil penelitian yang dipaparkan berupa (1) hasil belajar siswa, (2) uji asumsi, dan (3) uji hipotesis. Data hasil penelitian disajikan sebagai berikut. Data hasil belajar siswa yang diperoleh berupa nilai post-test antar kelompok siswa yang dalam proses pembelajarannya menggunakan media video dengan kelompok siswa yang dalam proses pembelajarannya tidak menggunakan media video namun sama-sama dibelajarkan menggunakan model pembelajaran konvensional. Berikut disajikan nilai rata- rata post-test, skor tertinggi, skor terendah, dan standar deviasi pada Tabel 2.

Tabel 2. Ringkasan nilai rata-rata post-test

\begin{tabular}{ccc}
\hline \multirow{2}{*}{ Statistik } & \multicolumn{2}{c}{ Nilai post-test } \\
\cline { 2 - 3 } & Kelas eksperimen & Kelas kontrol \\
\hline Rata-rata & 72,60 & 62,93 \\
\hline Standar deviasi & 6,54 & 8,41 \\
\hline Skor tertinggi & 83 & 80 \\
\hline Skor terendah & $\underline{60}$ & $\underline{50}$ \\
\hline
\end{tabular}

Berdasarkan data Tabel 2 diketahui nilai rata-rata post-test kelas eksperimen lebih baik dibandingkan dengan kelas kontrol $(72,60>62,93)$, berdasarkan nilai yang diperoleh, diketahui bahwa nilai post-test kelas eksperimen berkisar antara 60 sampai dengan 83 . Sementara itu, pada kelas kontrol nilai post-test berkisar antara 50 sampai dengan 80 . Ditinjau dari nilai standar deviasi, kelas eksperimen memiliki nilai standar deviasi yang lebih kecil dibandingkan dengan kelas kontrol $(6,54<8,28)$. Perbedaan nilai standar deviasi ini tidak terlalu jauh berbeda, hanya terjadi selisih sebesar 1,74. Hal ini mengindikasikan sebaran data pada kelas kontrol maupun kelas eksperimen tidak terlalu jauh berbeda. Dengan kata lain varians data pada kedua kelas bisa diasumsikan/dipandang homogen.

Sebelum melakukan uji hipotesis dengan menggunakan independent sample $t$-test, data yang diperoleh harus memenuhi uji asumsi. Uji asumsi dalam penelitian ini meliputi uji normalitas dan uji homogenitas varians antar kelompok. Hasil uji normalitas bahwa nilai signifikansi Kolmogorov-Smirnov dan Shapiro-Wilk untuk kelas eksperimen berturut-turut yaitu 0,200 dan 0,199. Sedangkan untuk kelas kontrol berturut-turut yaitu 0,200 dan 0,096. Berdasarkan nilai tersebut kedua kelas memiliki nilai signifikansi lebih besar dari 0,05 sehingga dapat dinyatakan sebaran data untuk kedua kelas berdistribusi normal.

Hasil uji homogenitas diperoleh nilai $F=0,974$ dengan signifikansi 0,327 sehingga nilai signifikansi yang diperoleh lebih besar dari 0,05 yaitu 0,327. Dengan demikian dapat dinyatakan bahwa varians data antar kelompok adalah homogen. Berdasarkan hasil uji normalitas danhomogenitas varians, diperoleh bahwa sebaran data hasil belajar siswa dalam mata pelajaran pekerjaan dasar elektromekanik pada kelompok eksperimen dan kelompok kontrol berdistribusi normal dan memilikivarians yang homogen. Oleh karena itu, uji hipotesis dapat dilakukan dengan uji-t dua ekor. Berdasarkan uji asumsi yang telah dilakukan, data nilai post-test telah memenuhi semua asumsi untuk diuji dengan menggunakan independent sample t-test. Hipotesis yang diuji dalam penelitian ini adalah sebagai berikut.

$\mathrm{H}_{0}$ : Tidak terdapat pengaruh penggunaan video terhadap hasil belajar siswa kelas $X$ TITL dalam mata pelajaran pekerjaan dasar elektromekanik di SMK Negeri 3 Singaraja.

$\mathrm{H}_{1}$ : Terdapat pengaruh penggunaan video terhadap hasil belajar siswa kelas X TITL dalam mata pelajaran pekerjaan dasar elektromekanik di SMK Negeri 3 Singaraja. 
Dalam penelitian ini kriteria untuk menentukan diterima/ditolaknya hipotesis statistik $\left(\mathrm{H}_{0}\right)$ apabila nilai signifikasi yang diperoleh lebih kecil dari 0,05 berarti $\mathrm{H}_{0}$ ditolak dan apabila nilai signifikansi lebih besar dari 0,05 berarti $\mathrm{H}_{0}$ diterima. Hasil uji-t disajikan pada Tabel 3.

Tabel 3. $t$-test for equality of means

\begin{tabular}{cccccc}
\hline & \multicolumn{2}{c}{$\begin{array}{c}\text { Levene's Test for Equality of } \\
\text { Variances }\end{array}$} & \multicolumn{3}{c}{$\begin{array}{c}\text { t-test for equality of } \\
\text { means }\end{array}$} \\
\hline & $\mathrm{F}$ & $\mathrm{Sig}$ & $\mathrm{t}$ & $\mathrm{df}$ & $\begin{array}{c}\text { Sig. (2- } \\
\text { tailed) }\end{array}$ \\
\hline $\begin{array}{c}\text { Equal variances } \\
\text { assumed }\end{array}$ & 0,974 & 0,327 & 5,210 & 63 & 0,000 \\
\hline $\begin{array}{c}\text { Equal varians not } \\
\text { assumed }\end{array}$ & & & 5,229 & 60,558 & 0,000 \\
\hline
\end{tabular}

Berdasarkan Tabel di atas nilai sig. (2-tailed) adalah 0,000 lebih kecil dari 0,05. Dengan demikian dapat diambil keputusan bahwa $\mathrm{H} 0$ ditolak dan $\mathrm{H} 1$ diterima. Dengan kata lain, dapat ditarik kesimpulan"terdapat pengaruh positif penggunaan video terhadap hasil belajar siswa kelas X TITL dalam mata pelajaran pekerjaan dasar elektromekanik di SMK Negeri 3 Singaraja".

Hasil analisis deskriptif mendeskripsikan perbedaan skor rata-rata hasil belajar dalam pembelajaran pekerjaan dasar elektromekanik antara siswa yang mengikuti pembelajaran dengan menggunakan media video dan siswa yang mengikuti pembelajaran tanpa menggunakan media video. Setelah kedua Kelas diberikan perlakuan yang berbeda didapat bahwa, (1) Siswa yang mengikuti pembelajaran dengan menggunakan media video memiliki skor rata-rata 72,60, (2) siswa yang mengikuti pembelajaran tanpa menggunakan media video memiliki skor rata-rata 62,93. Kualifikasi skor rata-rata hasil belajar siswa dalam pembelajaran pekerjaan dasar elektromekanik kedua kelas berbeda terlihat dari kelas yang menggunakan media video mendapatkan skor rata-rata yang lebih besar dibandingkan dengan kelas yang tidak menggunakan media video. Ini berarti bahwa pembelajaran pekerjaan dasar elektromekanik dengan menggunakan media video dapat memberikan kontribusi yang berarti dan cocok diterapkan untuk menciptakan proses belajar yang lebih bermakna serta menghasilkan keluaran berupa hasil belajar siswa yang lebih optimal.

Berdasarkan hasil uji hipotesis untuk tes hasil belajar siswa dalam pembelajaran pekerjaan dasar elektromekanik siswa diperoleh $t_{\text {hitung }}=5,210$ dan $t_{\text {tabel }}=1.998$ yang menunjukan bahwa $t_{\text {hitung }}>\mathrm{t}_{\text {tabel. }}$. Oleh karena itu $\mathrm{H}_{0}$ ditolak dan $\mathrm{H}_{1}$ diterima yang menunjukkan bahwa hasil belajar dalam pembelajaran pekerjaan dasar elektromekanik siswa yang mengikuti pelajaran dengan menggunakan media video lebih tinggi dari pada hasil belajar siswa yang mengikuti pembelajaran tanpa menggunakan media video. Dengan kata lain, ada pengaruh positif dari penggunaan media video terhadap hasil belajar siswa dalam mata pelajaran pekerjaan dasar elektromekanik. Berdasarkan data deskriptif dan data uji hipotesis didapatkan hasil bahwa kelas yang menggunakan media video dalam pembelajaran pekerjaan dasar elektromekanik mendapatkan hasil yang lebih besar dari pada kelas yang tidak menggunakan media video, maka dapat dikatakan bahwa media video dapat memberikan pengaruh positif terhadap hasil belajar siswa.

Seperti yang dikemukakan oleh Cecep Kustandi (dalam Nugroho, 2015), Cecep Kustandi menyatakan bahwa media pembelajaran adalah alat yang dapat membantu proses belajar mengajar dan berfungsi untuk memperjelas makna pesan yang disampaikan guru, sehingga dapat mencapai tujuan pembelajaran dengan lebih baik dan sempurna. Sesuai dengan pernyataan yang dikemukakan oleh Cecep Kustandi media pembelajaran yang digunakan pada kelas X TITL SMK Negeri 3 Singaraja dapat mempengaruhi hasil belajar siswa sehingga terdapat perbedaan dari hasil belajar siswa yang menggunakan media video dengan kelas yang tidak menggunakan media video. 
Dengan adanya video yang ditayangkan dalam proses pembelajaran siswa menjadi lebih memahami materi yang diberikan, seperti yang dijelaskan oleh Cecep Kustandi media video dapat memudahkan siswa untuk memahami materi sehingga ketertarikan siswa menjadi meningkat dan hasil belajar akan meningkat seiring bertumbuhnya ketertarikan siswa terhadap adanya penggunaan media video.

\section{Kesimpulan dan Saran}

Berdasarkan hasil penelitian dan pembahasan yang telah diuraikan, rata-rata hasil belajar siswa kelas X Teknik Instalasi Tenaga Listrik SMK Negeri 3 Singaraja dalam pembelajaran pekerjaan dasar elektromekanik yang menggunakan media video mendapatkan hasil belajar lebih tinggi, yaitu 72,69 sedangkan siswa yang tidak menggunakan media video mendapatkan hasil belajar yang rendah, yaitu 62,97 sehingga terdapat perbedaan hasil belajar yang didapatkan oleh kedua kelas. Dengan kata lain, terdapat pengaruh positif penggunaan media video terhadap hasil belajar siswa dalam pembelajaran pekerjaan dasar elektromekanik.

Berdasarkan hasil penelitian di atas, dapat diajukan beberapa saran yaitu, (1) Kepada guru, penerapan visualisasi melalui media video pada pembelajaran pekerjaan dasar elektromekanik dapat digunakan sebagai alternatif media pembelajaran untuk menyampaikan konsep-konsep berdasarkan aspek kajian pekerjaan dasar elektromekanik sehingga hasil belajar siswa meningkat, (2) Kepada siswa, penggunaan media video dapat digunakan sebagai sumber belajar tambahan selain buku pelajaran yang ada disekolah untuk menunjang belajar mandiri, (3) Kepada pihak sekolah diharapkan lebih sering memanfaatkan teknologi khususnya penggunaan media video dalam proses pembelajaran.

\section{Daftar Pustaka}

Agung, A A Gede. 2014. Metodologi Penelitian Pendidikan. Malang, Aditya Media Publishing.

Arikunto, S. 2005. Manajemen Penelitian (Edisi Revisi). Jakarta, PT Asdi Mahasatya. Candiasa, I M. 2010a. Pengujian Instrumen Penelitian Disertai Aplikasi ITEMAN dan BIGSTEPS. Singaraja, Universitas Pendidikan Ganesha.

Candiasa, I M. 2010. Statistik Univariat dan Bivariat Disertai Aplikasi SPSS. Singaraja, Universitas Pendidikan Ganesha.

Sugiyono, 2015, Metode Penelitian Pendidikan: Pendekatan Kuantitatif, Kualitatif, dan R\&D. Alfabeta Bandung.

Nugroho, 2015. Pengaruh Penggunaan Media Video Pembelajaran Terhadap Keterampilan Proses IPA Dan Hasil Belajar Ipa Pada Siswa Kelas V Sd Negeri Rejowinangun 1 Yogyakarta Tahun Ajaran 2014/2015". Skripsi (tidak diterbitkan), Universitas Negeri Yogyakarta. 